\title{
Anthós
}

6-2009

\section{The Impacts of Gentrification on the African American Business Community of Portland, Oregon}

Alexandra Hosford

Portland State University

Follow this and additional works at: https://pdxscholar.library.pdx.edu/anthos

Part of the Urban Studies Commons, and the Urban Studies and Planning Commons Let us know how access to this document benefits you.

\section{Recommended Citation}

Hosford, Alexandra (2009) "The Impacts of Gentrification on the African American Business Community of Portland, Oregon," Anthós: Vol. 1: Iss. 1, Article 2.

https://doi.org/10.15760/anthos.2009.1

This open access Article is distributed under the terms of the Creative Commons Attribution-NonCommercialShareAlike 4.0 International License (CC BY-NC-SA 4.0). All documents in PDXScholar should meet accessibility standards. If we can make this document more accessible to you, contact our team. 


\section{The Impacts of Gentrification on the African American Business Community of Portland, Oregon}

\section{Introduction}

The study of the persistence of residential segregation by race has become an area of keen interest for scholars, community organizers, and policy-makers alike. Inquiries made in this subject area enhance our understanding of how racial residential segregation affects such vital urban concerns as poverty concentration, access to public services, employment, and social mobility opportunities. While segregation exists between Caucasians (whites) and most minority groups, none have been so severe or widespread as the segregation that has historically occurred between whites and African Americans (blacks). A field of study has emerged examining the economic implications of residential segregation for communities of color.

Within that context, entrepreneurship has been identified as an important indicator of overall economic wellbeing within a community and proves to be an area of interest because, while gaps in educational attainment, employment, and income levels between blacks and whites have decreased measurably during the $20^{\text {th }}$ century (Sethi and Somanathan, 2004; Fairchild, 2008), rates of entrepreneurship have changed relatively little for segregated communities of color (Fairchild, 2008). The purported benefits of entrepreneurship have far-reaching implications for community wellbeing, including pathways to social and professional mobility, wealth creation and political power (Charles, 2003). Self-employment has also become an integral part of policies designed 
to improve the wellbeing of groups with low educational attainment and income rates (Smith, 2005).

The question of how black entrepreneurship is affected by socioeconomic status and segregation has been raised, and Fairchild (2008) has found that the clustering of a black population has a positive effect on levels of entrepreneurship for communities with low educational attainment rates, while cross-racial interactions and integration have a particularly positive impact on black entrepreneurs who have received a college education. At the same time, Cutler and Glaeser (1997) find that exposure to positive role models, defined as anyone who has attended college whether or not they obtained a degree, may have a positive impact on the socioeconomic outcomes of members of a segregated community. They also find that blacks have more exposure to positive role models in cities with less residential segregation. Gentrification, the process by which middle class, relatively educated, and (usually) majority white individuals move into an economically depressed, typically black, neighborhood and create economic and housing improvements, provides a unique opportunity to examine this hypothesis and to measure whether entrepreneurs and business owners within a community have been able to benefit from cross-racial interactions. While numerous studies have been conducted examining the social and migration aspects of gentrification, empirical evidence concerning the economic effects of gentrification for residents of color, either long term or more recent, is limited. 
I focus this inquiry on the impact that gentrification has had on black business and entrepreneurship in the Albina District of Portland, Oregon. The Albina district of provides a unique opportunity to measure the effects of gentrification on black business and business development because the area has historically been a residentially segregated black community and has seen dramatic changes due to gentrification in the past decade, including an influx of middle class, white residents. I conduct this examination by subdividing my inquiry into three main sections. First, I provide an outline of the background and evolution of the discourse around gentrification and segregation, both in a U.S. and Portland-specific context, and define the connection between gentrification and the larger area of inquiry focused on racial residential segregation. In the second section, I present an analysis of demographic and housing characteristics in four Inner Northeast Portland census tracts, using them as a proxy for measuring overall change within the historically black neighborhoods of Portland. In the third section, I outline findings from interviews conducted with local entrepreneurs and members of economic development organizations in order to give a localized perspective to the effects of gentrification in Inner Northeast Portland.

\section{Residential Segregation}

For most of the $20^{\text {th }}$ century, racial residential segregation has been viewed as a key aspect of overall racial inequality, since, whether voluntary or involuntary, exclusion from areas that contain valuable resources based upon race has serious implications for social and economic mobility and inter-group relations (Charles, 2003). It has been suggested that segregation may not be necessarily bad if it allows for mixing between 
economic income groups within a segregated community (Cutler and Glaeser, 1997). This, however, has not been the case, and it is segregation's tendency to concentrate people of similar socioeconomic status and demographics that is of primary concern. This combination racial segregation and concentrated poverty is particularly pronounced within inner city districts of large urban areas, especially in the Midwest and Eastern United States. The people who inhabit these areas are isolated from beneficial physical, social, and economic opportunities and resources (Fairchild, 2008). It has consistently been found that blacks within severely segregated communities have significantly worse socioeconomic outcomes in these areas than blacks in more integrated communities (Cutler and Glaeser, 1997; Charles, 2003; Massey and Denton, 1993; Timberlake, 2002).

It has been argued that social class factors outweigh race as a determining factor in social and economic wellbeing. Wilson makes this argument in his seminal work, The Truly Disadvantaged (Wilson, 1987). He maintains that inner city neighborhoods suffered from a combination of factors that led to high concentrations of poverty. The reduction of bluecollar production jobs, generally located in the inner city and disproportionately held by blacks, (Charles, 2003) and the movement of well paying service jobs to the suburbs, along with the exodus of middle and working class blacks from the central city, left the remaining residents persistently poor, physically isolated, and without the positive role models of the middle class to reinforce standard societal values (Sanchez-Jankowski, 1999). And the same negative attributes are widespread trend, affecting people beyond racial and ethnic lines. Massey and Denton find that between 1970 and 1990 overall 
income inequality and class segregation both increased, which suggests a growing concentration of both affluence and poverty (Massey and Denton, 2003).

However, the concentration of black poverty has remained fairly stable over this time period, while white poverty concentration has declined (Levy: Massey and Denton, 2003). It has also been found that low-income whites tend to have better access to resources and public goods and services within their neighborhoods than blacks of similar standing (Timberlake, 2002) and that outcomes for blacks are significantly worse in segregated cities than in more integrated ones, both in absolute terms and relative to whites (Cutler and Glaeser, 1997). These factors suggest that race and neighborhood location still play an important role in determining social and economic outcomes for individuals.

The publication of American Apartheid (Massey and Denton, 1993) marked a pivotal return in scholarly discourse to the subject of residential segregation (Charles, 2003) after an earlier decline in the literature. Their work took into account Wilson's argument for class segregation and the creation of an inner city 'ghetto underclass' (Charles, 2003) and argued that residential segregation, as a system, allowed for the deleterious effects of job loss and the exodus of middle and working-class blacks to take such strong hold in inner city black communities, since low income blacks were confined to their deteriorating neighborhoods. 
Historically, it was assumed that the passage of the Civil Rights Act in 1964 and the Fair Housing Act in 1968 would mark the beginning of the end of racial residential segregation (Charles, 2003; Massey and Denton 1993). Unfortunately, less formal mechanisms or "compulsions" to ensure that segregation remained became pervasive in urban areas across the country. These mechanisms varied from physical compulsions such as bombs, arson, and mobs; to social controls like segregation in schools and public facilities; to economic controls like the refusal of banks to make mortgage loans; and legalized compulsions that promoted slum clearance and urban renewal projects to be built through, or on top of, black neighborhoods (Gibson, 2007). Thus, segregation has remained the norm in the United State to the extent that, in the average American city, 60 percent of blacks would have to change residences in order to create an even distribution of races across neighborhoods (Cutler and Glaeser, 1997).

Additionally, while the mechanisms that allowed segregation to continue changed after the passage of formal legislation, so to did the geographic scale on which segregation takes place. Segregation on the state and county level "virtually disappeared" after the 1970's, while segregation on the neighborhood level increased from 1950 to the 1970 and city level segregation rose dramatically after 1970 (Massey and Hajnal, 1995). This shows a strong trend of segregation shifting from a macro-level to a micro-level issue.

\section{Economic Implications of Segregation}

Significant scholarly interest has emerged since the renewed interest in residential segregation surrounding the economic impacts of racial residential segregation, both 
positive and negative. Cutler and Glaeser (1997: 829) argue that the isolation that segregation engenders promotes a spatial mismatch between residents and jobs, and that "residents may learn few skills and acquire norms that are in conflict with mainstream society," hence creating social and intellectual isolation between groups. It has also been found that segregation and the concentration of poverty diminishes the accumulation of wealth from property values for blacks (Fairchild, 2008) and undermines overall rates of black home ownership (Charles, 2002). Massey and Denton argue that any process that concentrates poverty along racial lines simultaneously increases the odds of socioeconomic failure for members of that community (Massey and Denton, 1993). More positively, Michael Porter (1995) made the argument that the inner city holds several competitive business advantages over neighboring districts and the suburbs. He argues that inner city neighborhoods might offer outside firms a strategic business location, local uncaptured market demand, human resources, or integration with regional business clusters, while helping to create more economically viable areas. The connections made between firms and local residents, he argues, will benefit the economic outcomes of both parties.

Within the area of interest concerning the economic effects of segregation, academic interest has grown around the potential impact that increased levels of entrepreneurship could have upon a segregated community. Studies have shown a consistent 3-to-1 ratio between white and black self-employment (Fairchild, 2008) and the Small Business Administration reported that in 2001, African Americans were 12.3 percent of the total 
population, but owned just 4 percent of entrepreneurial small businesses, and earned only .4 percent of total receipts for all small businesses (Smith, 2005).

Many benefits have been put forward for increasing self-employment among minorities. Fairchild cites job growth, wealth creation and the establishment of a "cadre of economically-mindful community leaders" (Fairchild, 2008: 513) as ways in which a community could benefit from increased entrepreneurial activity. It is also argued that increasing entrepreneurship for minorities could lower tensions between ethnic groups in urban areas (Fairchild, 2008) and provide pathways to social and professional mobility, wealth creation and political power (Charles, 2003). Smith argues that entrepreneurs contribute to general economic development as well as development within their own group and contribute to community capital formation and self-esteem for owners and employees (Smith, 2005).

Scholars have remained divided on whether residential racial segregation provides a sheltered business environment, particularly for entrepreneurs, or whether it creates serious barriers to entry into the broader labor market. And indeed the results of studies have been mixed, showing that segregation hinders entrepreneurial endeavors for those with higher education levels, for whom cross-cultural ties are most beneficial, while it may provide a sheltered business environment for individuals with low educational attainments and immigrants (Fairchild, 2008). However, beyond entrepreneurship, segregation has been found to have an overall negative impact on the earnings of lowincome blacks (Cutler and Glaeser, 1997). It has additionally been reported that it is the 
more advantaged ethnic and racial groups who have the highest rates of self-employment, rather than immigrant or disadvantaged populations (Fairlie and Meyer, 1996). This suggests that less segregated populations may have better overall entrepreneurial outcomes, since they have access to outside resources and social and economic influences.

\section{Segregation in the City Of Portland}

Portland has not been exempt from the deleterious effects of racial segregation. Karen Gibson (2007) outlines the history of disinvestment in Portland's black neighborhoods, collectively known as the Albina district. The initial migration of blacks into Inner Northeast Portland and white residential and business flight in the 1960s and 1970s led to “economic stagnation, population loss, housing abandonment, crack cocaine, gang warfare, redlining and speculation" (Gibson, 2007: 17) in the 1980s. But the 1990s ushered in a new era for Albina: one of gentrification. Young, middle-class whites made their way back into an area of the city that had seen continual disinvestment and decline from many previous decades. For the first time "since the color line was hardened 1940, segregation fell below a level considered high" (Gibson, 2007: 20) while tensions between new and old residents grew.

One way to measure segregation is the racial dissimilarity index. This measures the evenness of racial distribution between statistical areas and indicates the percentage of a particular group that would have to spatially relocate in order to create an even distribution between two groups within a statistical area (Charles, 2003). Below is the 
dissimilarity index for the Portland-Vancouver metropolitan statistical area based off of figures from the 2000 decennial census, which shows an approximately $55 \%$ dissimilarity between blacks and whites.

\section{Dissimilarity Indices for Race \& Ethnic Groups}

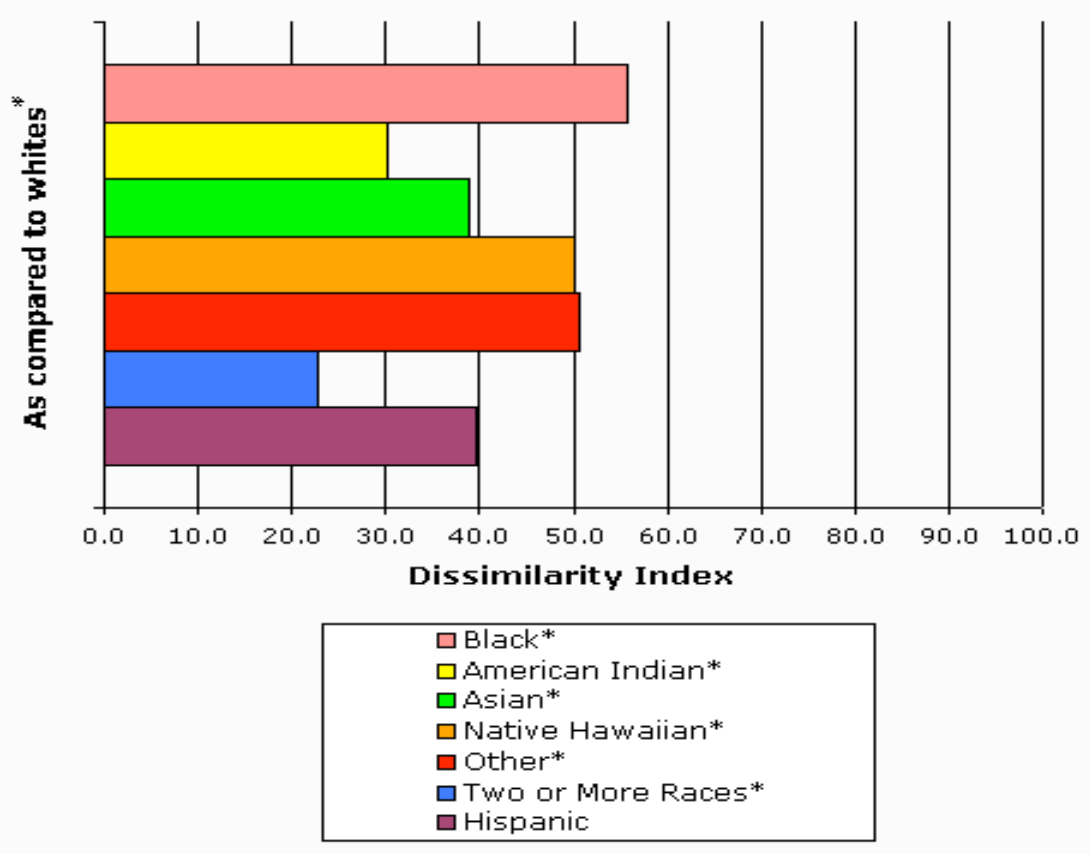

Source: censusscope.org

\section{Gentrification}

Gentrification has been called "one of the most controversial issues in the urban United States today" (Freeman, 2005: 463). Yet gentrification has shown a powerful ability to revitalize communities and appears to be an effective solution to long-term urban decay (Newman and Wyly, 2006). However, fear of displacement often breeds resistance from long-time residents and neighborhood institutions. Freeman, Braconi and Vigdor all brought the issue of displacement to the forefront of academic interest in gentrification (Freeman and Braconi, 2002; Vigdor, 2002). In their studies they find that, rather than 
increasing housing turnover rates for low-income households, gentrification actually decreases those rates, even though residents may be using a larger percentage of their income to pay for improved amenities in their neighborhood (Freeman and Braconi, 2004). These results have sparked substantial debate. Overall, the literature on gentrification seems to have a positive outlook. In the economic sphere, Byrne theorizes that existing residents should at the very least find expanding employment opportunities "in providing locally the goods and services that more affluent new residents can afford" (Byrne, 2003; p.6). Duany frames gentrification as the "rising tide that lifts all boats" (Duany, 2001: 37).

Yet concerns with the reality of displacement still exist (Newman and Wyly, 2008) along with questions of the true social benefits that an influx of middle class residents and their culture and values will have on the long-standing population. Newman and Wyly find higher rates of displacement than Freeman and Braconi in New York. They argue that, because the original study focuses on gentrification in the 1990's, it contains considerable bias and two generations of prior intense gentrification are not being considered in the measurement of overall displacement (Newman and Wyly, 2006). Freeman and Braconi's study also uses a subborough level of analysis, which is potentially large enough to overlook localized displacement (Freeman, 2005).

In interviews with residents of a gentrifying area Freeman also finds that, while gentrification may provide positive spillover effects for long-term residents in terms of access to resources, physical redevelopment and potential employment, tensions often 
arise between those who are a part of the original class and culture of the neighborhood and new residents' values. This leads to some questions as to whether new residents will have meaningful enough engagements with old residents to instill the values associated with the middle class (Freeman, 2006), including entrepreneurship and business ownership.

So, while quantitative and qualitative analyses have been conducted concerning the displacement and social impact factors of gentrification, a gap still remains in the literature regarding its economic impacts. Does the gentrification of an area provide the impetus for long-term residents and all residents of color to develop and maintain entrepreneurial practices? More specifically, has the black business community of Albina benefited from the physical, capital, and social changes associated with an influx of a middle class, white, and relatively educated population?

This question allows for two possible outcomes. If an influx of new residents from different socioeconomic backgrounds bring with them renewed economic vigor, physical redevelopment, and the social integration that is hypothesized to occur when an area is desegregated (Fairchild, 2008), then the rising tide should lift all boats and local residents, particularly local business owners and entrepreneurs, should benefit. On the other hand, if the increased cost of living associated with gentrification forces existing firms to relocate, hinders the starting of new companies by blacks, or if the clientele on which a black-owned business depends is displaced or leaves the neighborhood, then it can be posited that gentrification will have had a negative impact on local self- 
employment and entrepreneurship for black residents. This study will provide insight into the economic impacts that gentrification has had upon small-business development in the Albina district of Portland and create a groundwork for further inquiry.

\section{Methods}

To gain insight into the changes that have occurred in the Albina district, I have used a mixed methods approach consisting of two main components. First, I have outlined a set of criteria used to determine if gentrification is occurring within an area, and have compared those criteria to secondary data collected for the four census tracts that I am using as proxies for Albina neighborhoods, and to data from the larger PortlandVancouver, Washington metropolitan area. I then outline insights gained from first hand, in-depth interviews with stakeholders directly concerned with the economic outcomes of gentrification within the neighborhood.

To determine whether the changes that have occurred within the census tracts can be qualified as "gentrification" I will use the five measurements that are outlined by Freeman in determining whether or not gentrification is occurring in New York City neighborhoods (Freeman, 2005). While no universal definition of gentrification exists, Freeman outlines what are widely considered hallmark characteristics of gentrification: An area must be in a "(1) central city neighborhood location, (2) with a median income less than the median for the metropolitan region, (3) experiencing disinvestment, (4) and facing an influx of the relatively affluent, with a resultant (5) increase in investment" (Freeman, 2005). Freeman uses the age of housing stock as a proxy for disinvestment, since census data contains no direct measurements of investment or disinvestment. He 
argues that neighborhoods with the proportion of the housing stock built in the 20 years preceding the metropolitan median are candidates for gentrification. For criterion four, Freeman uses educational attainment as a proxy for affluence, since income may vary over time and it is often low-income artists and young professionals who pioneer gentrification. For the final criterion, Freeman uses an increase in housing prices as a proxy for reinvestment.

\section{Is Gentrification Occurring in the Albina District?}

The first qualification for gentrification outlined by Freeman is a central city location. I argue that the location of the Albina district in Inner Northeast Portland qualifies the area as central city for the purpose of this inquiry. The Albina district is very close to downtown, dates back to the Victorian era, and has historically held the black immigrant population of Portland, as have many inner-city neighborhoods in larger cities (Cutler, Glaeser, and Vigdor, 1999).

The next criterion for determining whether or not gentrification is taking place is the presence of a primarily low-income population. The table below shows the percentage rates of poverty within the four Albina census tracts in 1990 and 2000 against the rates for the entire Portland metropolitan area. This data makes it clear that poverty within the Albina census tracts is much more pervasive than in the metropolitan region, even with significant declines in the 2000 data. 


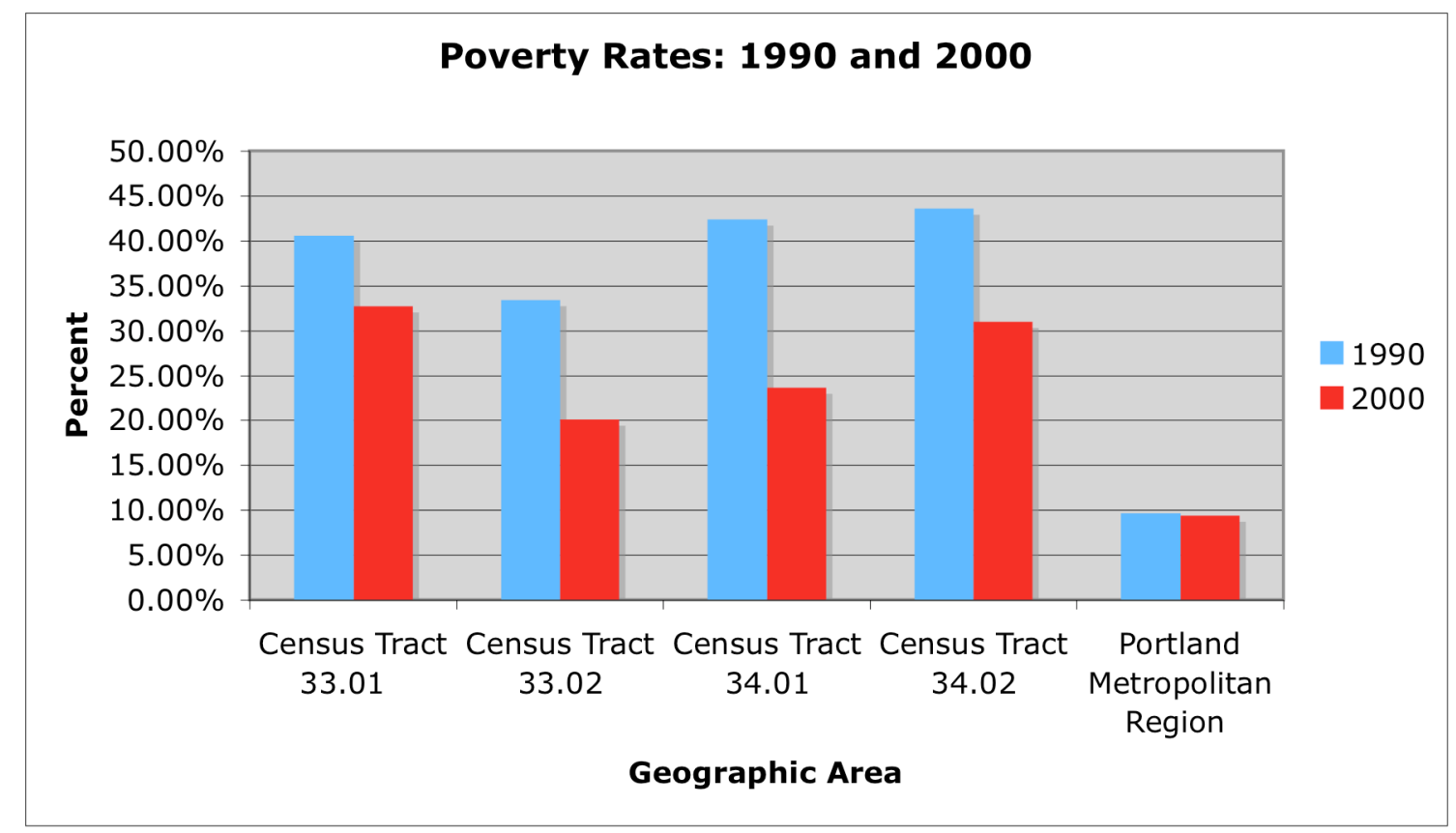

The third criterion is disinvestment. A vivid account of the disinvestment of the Albina district is portrayed in Gibson's article Bleeding Albina (Gibson, 2007) but is also reflected in census data. The table below outlines factors important for qualifying disinvestment, among them the age of the housing stock and the vacancy status rate. In 2000 the vacancy status for the census tracts had normalized to levels close to the metropolitan average, though still above it. The 1990 rates, however, suggest considerable levels of abandoned housing in the area. Next, as Freeman's indicator of overall disinvestment, the age of housing stock is an important factor in measuring disinvestment. Rather than measuring the proportion of housing stock built within the last 20 years, I have used the median age of housing stock, which is significantly older within the census tracts that within the metropolitan area, in both 1990 and 2000. 
Demographic and Housing Trends in Portland, Oregon: 1990-2000

\begin{tabular}{|c|c|c|c|c|c|}
\hline & \begin{tabular}{|l|} 
Census Tract \\
33.01
\end{tabular} & \begin{tabular}{|l|} 
Census Tract \\
33.02
\end{tabular} & $\begin{array}{l}\text { Census Tract } \\
34.01\end{array}$ & $\begin{array}{l}\text { Census Tract } \\
34.02\end{array}$ & $\begin{array}{l}\text { Portland } \\
\text { Metropolitan } \\
\text { Region }\end{array}$ \\
\hline $\begin{array}{l}\text { Total } \\
\text { Population } \\
\text { Percentage } \\
\text { Change }\end{array}$ & $\begin{array}{l}\text { 1990: } 2,538 \\
2000: 3,223 \\
26.9 \%\end{array}$ & $\begin{array}{l}\text { 1990: 2,545 } \\
2000: 2,494 \\
-2.0 \%\end{array}$ & $\begin{array}{l}\text { 1990: } 2,832 \\
\text { 2000: } 3,309 \\
16.8 \%\end{array}$ & $\begin{array}{l}\text { 1990: } 2411 \\
\text { 2000: } 2770 \\
14.8 \%\end{array}$ & $\begin{array}{l}1990: \\
1,477,895 \\
2000: \\
1,886,623 \\
\\
27.6 \%\end{array}$ \\
\hline $\begin{array}{l}\text { Population: } \\
\text { White } \\
\text { Percentage } \\
\text { Change: }\end{array}$ & $\begin{array}{l}\text { 1990: } 786 \\
\text { 2000: } 986 \\
\\
25.4 \%\end{array}$ & $\begin{array}{l}\text { 1990: } 939 \\
\text { 2000: } 1,142 \\
21.1 \%\end{array}$ & $\begin{array}{l}\text { 1990: } 719 \\
\text { 2000: } 1,154 \\
60.5 \%\end{array}$ & $\begin{array}{l}\text { 1990: } 561 \\
\text { 2000: } 950 \\
69.3 \%\end{array}$ & $\begin{array}{l}\text { 1990: } \\
\text { 1,350,155 } \\
2000: \\
\text { 1,621,090 } \\
\\
20.0 \%\end{array}$ \\
\hline $\begin{array}{l}\text { Population: } \\
\text { Black }{ }^{1} \\
\text { Percentage } \\
\text { Change: }\end{array}$ & 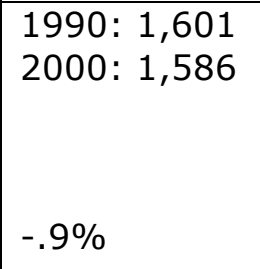 & \begin{tabular}{|l|}
$1990: 1,472$ \\
$2000: 937$
\end{tabular} & $\begin{array}{l}\text { 1990: } 1,952 \\
\text { 2000: } 1,592 \\
-18.4 \%\end{array}$ & $\begin{array}{l}\text { 1990: } 1,693 \\
2000: 1,282\end{array}$ & $\begin{array}{l}1990: \\
41,671 \\
2000: \\
51,425 \\
23.4 \%\end{array}$ \\
\hline $\begin{array}{l}\text { Households } \\
\text { Percentage } \\
\text { Change: }\end{array}$ & \begin{tabular}{|l|}
$1990: 833$ \\
$2000: 1,134$
\end{tabular} & $\begin{array}{l}\text { 1990: } 879 \\
\text { 2000: } 994 \\
\\
13.0 \%\end{array}$ & $\begin{array}{l}\text { 1990: } 1,080 \\
2000: 1,228 \\
13.7 \%\end{array}$ & $\begin{array}{l}\text { 1990: } 829 \\
\text { 2000: } 1,029 \\
24.1 \%\end{array}$ & $\begin{array}{l}\text { 1990: } \\
575,531 \\
2000: \\
741,776 \\
\\
28.8 \%\end{array}$ \\
\hline $\begin{array}{l}\text { Housing } \\
\text { Units } \\
\text { Percentage } \\
\text { Change: }\end{array}$ & $\begin{array}{l}\text { 1990: } 1064 \\
\text { 2000: } 1194\end{array}$ & $\begin{array}{l}\text { 1990: } 1053 \\
\text { 2000: } 1118\end{array}$ & $\begin{array}{l}\text { 1990: } 1316 \\
\text { 2000: } 1325 \\
.6 \%\end{array}$ & $\begin{array}{l}\text { 1990: } 1063 \\
\text { 2000: } 1144 \\
7.6 \%\end{array}$ & $\begin{array}{l}\text { 1990: } \\
605,513 \\
2000: \\
786,300 \\
\\
29.8 \%\end{array}$ \\
\hline $\begin{array}{l}\text { Vacancy } \\
\text { Status } \\
\text { (Total) }\end{array}$ & $\begin{array}{l}\text { 1990: } 21 \% \\
2000: 8.1 \%\end{array}$ & \begin{tabular}{|l|}
$1990: 16.5 \%$ \\
$2000: 7.7 \%$
\end{tabular} & $\begin{array}{l}\text { 1990: } 17.9 \% \\
2000: 7.3 \%\end{array}$ & $\begin{array}{l}\text { 1990: } 22.0 \% \\
2000: 10.0 \%\end{array}$ & $\begin{array}{l}\text { 1990:4.9\% } \\
\text { 2000: } 5.6 \%\end{array}$ \\
\hline $\begin{array}{l}\text { Self- } \\
\text { Employment } \\
\text { Income }\end{array}$ & \begin{tabular}{|l|} 
1990: $9.8 \%$ \\
2000: $12.8 \%$
\end{tabular} & $\begin{array}{l}\text { 1990: } 8.5 \% \\
\text { 2000: } 12.1 \%\end{array}$ & $\begin{array}{l}\text { 1990: } 10.5 \% \\
2000: 13.0 \%\end{array}$ & $\begin{array}{l}\text { 1990: } 5.7 \% \\
2000: 14.5 \%\end{array}$ & $\begin{array}{l}1990: 5.6 \% \\
\text { 2000: } 14.3 \%\end{array}$ \\
\hline $\begin{array}{l}\text { Median year } \\
\text { structure } \\
\text { built }\end{array}$ & $\begin{array}{l}\text { 1990: } 1944 \\
\text { 2000:1939 }\end{array}$ & $\begin{array}{l}1990: 1940 \\
2000: 1939\end{array}$ & $\begin{array}{l}\text { 1990: } 1940 \\
2000: 1939\end{array}$ & $\begin{array}{l}\text { 1990: } 1940 \\
\text { 2000: } 1939\end{array}$ & \begin{tabular}{|l|} 
1990: 1974 \\
2000: 1967
\end{tabular} \\
\hline
\end{tabular}

${ }^{1}$ Comparing the black population from the 2000 decennial census is difficult because respondents were given the option to identify multiple ethnicities for the first time 


\begin{tabular}{|c|c|c|c|c|c|}
\hline Poverty Rate & $\begin{array}{l}\text { 1990: } 40.6 \% \\
2000: 32.7 \%\end{array}$ & $\begin{array}{l}\text { 1990: } 33.4 \% \\
\text { 2000: } 20.1 \%\end{array}$ & $\begin{array}{l}\text { 1990: } 42.4 \% \\
2000: 23.7 \%\end{array}$ & $\begin{array}{l}\text { 1990: } 43.6 \% \\
\text { 2000: } 31.0 \%\end{array}$ & $\begin{array}{l}\text { 1990: } 9.7 \% \\
2000: 9.4 \%\end{array}$ \\
\hline $\begin{array}{l}\text { White } \\
\text { Educational } \\
\text { Attainment: } \\
\text { Some } \\
\text { College or } \\
\text { Above }\end{array}$ & $\begin{array}{l}\text { 1990: } 29.6 \% \\
\text { 2000: } 43.7 \%\end{array}$ & $\begin{array}{l}\text { 1990: } 27.1 \% \\
2000: 63.9 \%\end{array}$ & $\begin{array}{l}\text { 1990: } 27.9 \% \\
2000: 42.0 \%\end{array}$ & $\begin{array}{l}\text { 1990: } 23.7 \% \\
2000: 46.6 \%\end{array}$ & $\begin{array}{l}\text { 1990: } 38.7 \% \\
2000: 43.8 \%\end{array}$ \\
\hline $\begin{array}{l}\text { Black } \\
\text { Educational } \\
\text { Attainment: } \\
\text { Some }\end{array}$ & $\begin{array}{l}\text { 1990: } 17.5 \% \\
2000: 17.5 \%\end{array}$ & $\begin{array}{l}\text { 1990: } 21.4 \% \\
\text { 2000: } 27.1 \%\end{array}$ & $\begin{array}{l}\text { 1990: } 19.3 \% \\
\text { 2000: } 22.9 \%\end{array}$ & $\begin{array}{l}\text { 1990: } 21.3 \% \\
\text { 2000: } 24.5 \%\end{array}$ & $\begin{array}{l}\text { 1990: } 25.9 \% \\
2000: 28.7 \%\end{array}$ \\
\hline $\begin{array}{l}\text { College or } \\
\text { Above }\end{array}$ & $0 \%$ & $26.6 \%$ & $18.6 \%$ & $15.0 \%$ & $10.8 \%$ \\
\hline
\end{tabular}

Source: U.S. Census Bureau

The fourth criterion necessary to determine whether or not gentrification has taken place is the ability to indicate that an influx of the "gentry" has occurred, measured through educational attainment rates. Above, it is clear that the educational attainment rates for whites met or exceeded metropolitan averages, except in the case of census tract 34.01 . While those levels may not prove an exceptional influx of middle and upper-class residents given Freeman's model, educational attainment rates for whites were well below the metropolitan average in 1990, showing a dramatic increase in attainment rates between decades. On the other hand, black educational attainment remained below the average in both 1990 and 2000 in all four census tracts and remained almost constant in every census tract but 33.02 .

The last criterion is an increase in investment, measured through an increase in housing value by Freeman. According to the Coalition for a Livable Future's Regional Equity Atlas, home prices in areas of Inner Northeast Portland rose by over 100\% between 1995 and 2004 (Regional Equity Atlas, map 3-1a). 
Overall, the area meets the qualifications to be considered gentrifying. It also shows other signs typical of gentrification, including a dramatic decline in the black population coinciding with a significant increase in the white population and a sharp decrease in poverty rates within the census tracts. This suggests that as white residents moved into the area, they brought investment and a higher socioeconomic status with them, resulting in the extraordinary increases in property value and the movement of black and impoverished residents out of the neighborhood.

\section{Economic Implications}

Since Albina does indeed qualify as a gentrifying area, what are the economic implications for the black business community? Have long-standing black-owned businesses been able to stay afloat and have new black entrepreneurs been able to start up new businesses? And, overall, has the black business community benefited from gentrification? Interestingly, as seen in the chart above, the percent of individuals claiming income from self-employment rose within the census tracts between 1990 and 2000. In the following section, I will address the above questions by recounting insights provided by interviews with business owners and organizational representatives.

\section{The History of Gentrification: Reports from the Community}

For my interviews I used a semistructured interview method and spoke with local residents and people who have been involved with the gentrification process in Albina. Questions were preformulated, but the answers were open-ended and the discussions 
were enhanced by probe questions (Schensul et al, 1999). I selected this method because I wanted the interviews to have the flexibility of a conversation and allow interviewees to discuss and elaborate upon topics that may not have been emphasized in my questions. I had a set of core questions, which I asked every interviewee, and then had a set of questions specific to business owners and to development workers ${ }^{2}$. In some cases the two categories overlapped, in which case the questions were combined. In many cases, after a brief prompting, interviewees would cover several subject areas without direct questioning.

During my interviews, I was surprised by a particular recurring phenomenon. In each interview I asked the participant if they would recount for me the changes that they had seen in the Albina District. Sometimes I specified an elaboration on 'recent history' or 'changes due to gentrification,' but with few exceptions, regardless of my wording of the question, interviewees described changes in the area stretching back much further. They described changes that they had seen over the course of their lifetime, the time that they had been a part of the community, or reaching beyond personal experience into the history of the area. This highlighted for me the necessity to analyze gentrification not a phenomenon occurring in historical isolation, but is the result of many historical and present-day forces. Karen Gibson, who has done significant research on the history of Albina recounted its history.

${ }^{2}$ See the Appendix for a complete list of questions 
"Back in the 1800's [Albina] was settled by the immigrants. They weren't allowed to live in Portland so they created their own city. This was a very vibrant, good neighborhood."

Blacks moved to Portland and cities across the west coast in greater numbers for jobs during World War Two. After the war, efforts were made to force blacks to leave the area (Gibson, 2007). "The attitude of the existing population was that 'you came here for the war, but you must go now. You are not wanted here." Auxiliary unions had been created for blacks because "they didn't want people to stay, and that if they had invited them into unions then they would have wanted to stay more" (Gibson).

Interviewee 3, a longstanding member of the Albina community, echoed this sentiment saying "honestly Portland did not want [blacks] to stay. They wanted them to go away. Some of them did. But some of them had no place to go. Some of them had come from a place that was not as nice as Portland, and some of them just simply had their roots here and they wanted to stay. Portland forced them all to live in one area."

When the original black settlement, Vanport, was flooded when a dam on the Columbia River burst (Gibson, 2007) the black population that had remained in Portland moved to the Albina District. Interviewee 3 described the redlining and financial segregation that occurred, which forced black families to stay in Albina. "They made them stay here. Then, what was worse is [the city] started neglecting the infrastructure of the community." 
Sam Brooks described the extreme segregation that he saw when he first came to

Portland as a member of the military in 1968.

"Our ship was tied up down at Swan Island and I came to Portland, uh, went downtown Portland, uh. I didn't see a single African American in town, so I, you know walked all the streets of downtown, so I finally just stopped somebody on the street and said 'are there any black people that live in Portland?"”

As I spoke with community members, a timeline began to emerge with relationships between historical events and their impacts on the community. Great emphasis was placed on gentrification, but also on the urban renewal of the 1950s and 1960s. In fact, gentrification was stressed as an effect of earlier neighborhood degradation caused largely by urban renewal and other institutional mechanisms. A life-long Portland resident and activist in the black community, Interviewee 5 described for me the evolution of the black business community during his lifetime.

"When I was a youngster there was lots of black-owned businesses in Inner North, Northeast, and even into Northwest Portland and that has changed substantially, not necessarily through gentrification.”

\section{Urban Renewal}

Albina was impacted more than any other area of Portland by urban renewal. The Housing Act of 1957 permitted slum clearance, allowing local officials to designate areas of Albina as "blighted" and target them for large construction projects aimed at stopping the spread of urban decay throughout the city. The area of Albina directly across the river from downtown, made up by the Eliot, Lloyd, and Irvington neighborhoods, became the focal point of urban renewal development in Portland. The following is an excerpt from the Portland Development Commission's proposal for urban renewal projects: 
There is little doubt that the greatest concentration of Portland's urban blight can be found in the Albina area encompassing the Emanuel Hospital. This area contains the highest concentration of low-income families and experiences the highest incidence rate of crime in the City of Portland. Approximately $75 \%$ to $80 \%$ of Portland's Negro population live within the area. The area contains a high percentage of substandard housing and a high rate of unemployment. Conditions will not improve without a concerted effort by urban renewal action. The municipal goals as established by the Community Renewal Program for the City of Portland further stress the urgent need to arrest the advanced stages of blight. (Gibson, 2007; Portland Development Commission 1966:17)

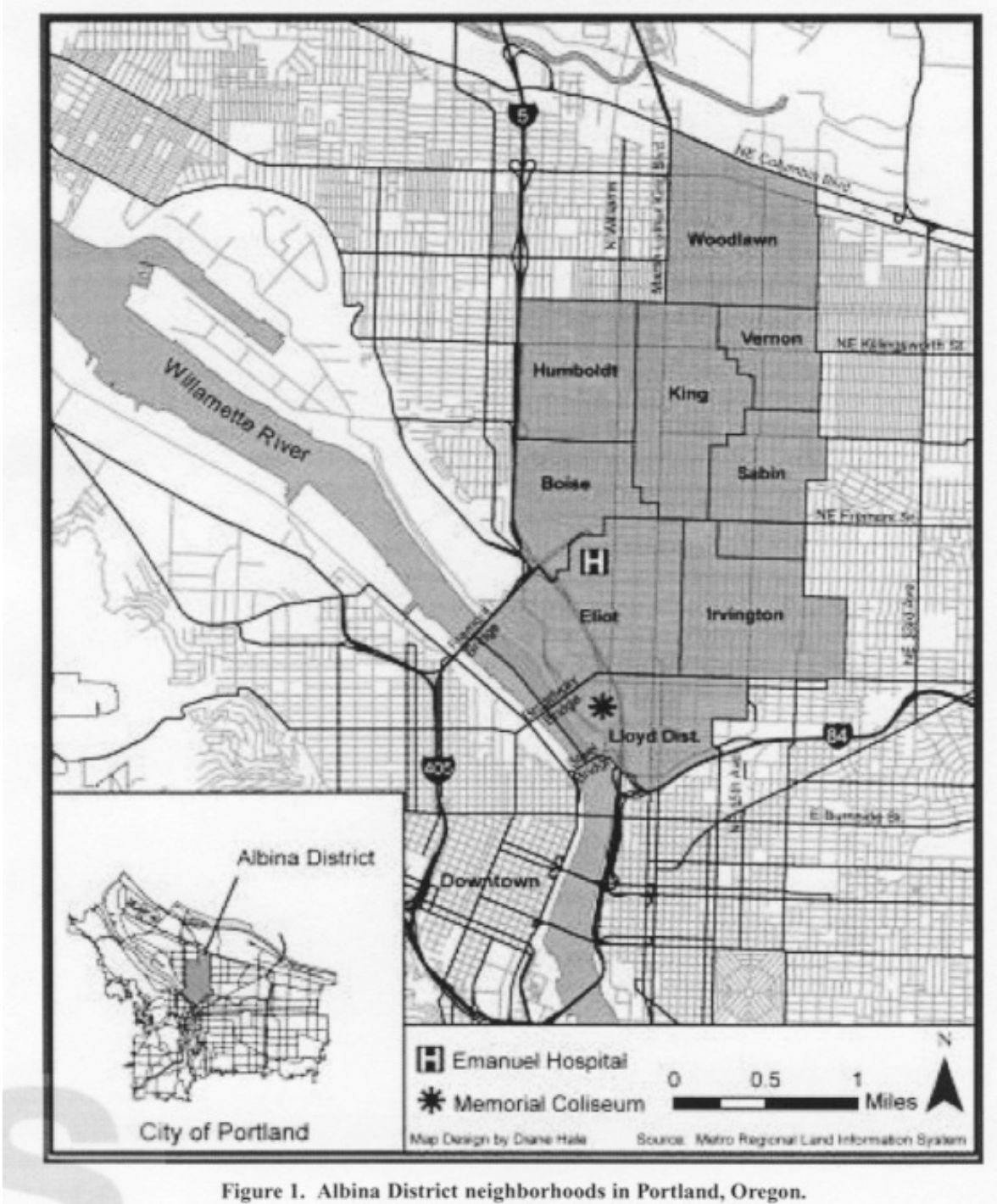

Image Source: Bleeding Albina (Gibson, 2007)

In 1956, construction of the Memorial Coliseum was approved by city voters, destroying "commercial establishments and 476 homes, roughly half of them inhabited by African 
Americans" (Gibson, 2007: 11). Interstates 5 and Highway 99 were also constructed through the Albina district, made possible by the Federal Aid Highway Act of 1956. The Legacy Emauel Hospital, which was already located in the area, was largely expanded and new buildings were constructed during urban renewal. The city built these projects in lower Albina, the area that was largely considered the economic and social heart of the black community.

"When they destroyed that area, the Emanuel area, that was like huge, okay? That was the strength. I mean, as far as I can see that's when people were strongest was in the " $60 \mathrm{~s}$. You know, they did have some housing. Because of the segregation it helped them kind of have their own markets...before the influx of drugs and the years and years of redlining" (Gibson Interview, 2009).

Interviewee 5 described the impact of urban renewal to me in this way:

"Urban Renewal was the biggest - and maybe people consider urban renewal gentrification, I don't know-but certainly it was probably the single largest influencer of eliminating African American businesses in my lifetime in Portland. And when I think about when I was a kid, all of the businesses that were along all around Emanuel Hospital, that area right around Emanuel and right below it where they eventually put in the freeway and the coliseum. I mean, that was kind of the heart of the black community. Lots of black businesses down there, you know, barber shops, grocery stores, dry cleaners, night clubs, a lot of night clubs. Lots of things down there and those things went pretty quickly."

After urban renewal razed lower Albina, the black population relocated to the King, Boise, and Humbodt neighborhoods of upper Albina, making blacks the majority population in those areas for the first time (Gibson, 2007). Interviewees then began to describe the degradation that occurred in the area in the 1970s and 1980s. Karen Gibson told me about the state of the education system in Albina during that period:

"[there was] no middle school in the community for many many years...I've read that people in their 50's actually have psychological scars from when they were bussed out [of the community] okay? From the school experiences that 
they had here. Can you imagine no middle schools in the community at all, during the, I think, 70's and 80's?"

This has a direct implications overall wellbeing of the community and specifically the business community because "effectively, when people do not get access to a decent education, they--you're completely cutting them off from that labor market competition" (Gibson interview, 2009).

Two business owners that I interviewed discussed the dilapidated and unsafe state of the neighborhood before gentrification began taking place. Sam Brooks is an African American business owner on Alberta Street, now a flourishing business corridor promoted now as the "Alberta Arts District.” He said that in the late 1980s “... it was too dangerous to even drive along Alberta, let alone walk."

Interviewee 3, has owned the building in which her business is located on Mississippi Avenue - another thriving business corridor in Albina-for 20 years. She described the state of the neighborhood when she moved there as very run-down and unsafe.

"When I bought this building it had been abandoned and boarded up for 30 years. Unfortunately, that was the state of most of the businesses and buildings in the neighborhood. Now, when I bought this building there were 40 active businesses on Mississippi between Fremont and Skidmore--40-some businesses. All of them operated behind closed doors or boarded up. There were two businesses that were open to the public. The New Rite store was operated by a Korean family...the other little store was a little store run by two Vietnam veterans, I mean they were black men, and they hired a man to sit on a stool all day long and say 'don't steal. Put that back.' They, at that time, were selling more liquor than they were food... what they were selling was majority booze. Booze and cigarettes...the drug traffic, the prostitution, the criminal activities were the number one businesses on the street." 
The other businesses that Interviewee 3 described along Mississippi were industrial businesses that were not open to the public. She described the illegal activity and violence as being very visible and prominent in public, while ordinary citizens stayed in their homes and off of the streets.

"There were a lot of very bad people in this neighborhood. You saw them on the streets. There were a lot of very good people living in this neighborhood. They stayed behind their closed doors. It wasn't safe for them to be out on the street...it was a very bad neighborhood. It was probably the most crime-ridden neighborhood, the worst neighborhood in the entire community."

She recounted stories of elderly neighbors afraid to leave their house or to call the police because drug dealers dealt from their porch. She told me of a fellow business owner who was mugged at knifepoint and "left for dead" by another neighbor and of being shot at through the windows of her store--"thankfully they're not very good shots," she said.

Repeatedly in these interviews, the weakness of the community was emphasized, especially when talking about the degradation that occurred after urban renewal and in relation to the shift that began to occur in the early 1990s, taking Albina from a declining community to a gentrifying one.

"When the drug people came up from California they invaded a community that was weak, who didn't have political strength, who didn't have economical strength and, in many cases, didn't have the educational strength to do what they needed to do to stop it. They said 'help us' and the rest of the community said 'we don't see a problem." (Interviewee 3)

Albina had been unable to withstand the rising tide of violence, drug, and gang activity that followed urban renewal. In the early 1990s community members began organizing to 
improve the area, but it remained to be seen whether or not the community could endure through its revitalization as well.

\section{Gentrification: A Social Movement Moves to Government}

Three of the people I interviewed, Sam Brooks and Interviewees 3 and 5, were all directly involved in the community action that began to change the neighborhood. Interviewee 5 discussed the local government's approach to development, which was to meet with citizen groups and formulate plans based off of what they thought they heard from the community. The Interviewee noted:

“...that wasn't working, that wasn't satisfactory, because in the end what they ended up with was what they already thought, you know, kind of going into it.

They kind of picked from the commentary and support and so forth, the conversations around the community that kind of supported what they thought was the right answer. So we wanted a new model."

He and other members of the community began organizing meetings where members of the community could discuss what changes they wanted to see in the neighborhood.

"The idea of pulling that organization together was to get as many people who worked and lived and played in Northeast Portland to get together around the table and kind of define what it was that they wanted to see happen in Inner Northeast...they included the city in this conversation but everybody kind of had an equal vote here, so the city didn't hold some sort of magic stick or wand. There was no money on the table so there was never an issue about budget or money or anything like that, so all of this was developed with the idea that 'no we don't have money, but who knows? Someday we might and if there is, this is what we want to do."”

Sam Brooks began to envision changes specific to the Alberta Street corridor. He called his ideas Project Alberta.

“Alberta's kind of the hot street in Portland now. It was my idea, back in 1991, period. And I went to the PDC and started talking about Project Alberta and the, 
the school of architecture from the University of Oregon--students, undergraduates just like you, did all of these [drawings and plans]. They came and spent two months with us trying to get 'what are the ideas and what might

Alberta Street look like?' and then come up with a rendering that reflected that... and if you look at Alberta Street now, they were not too far off the mark."

While Mr. Brooks and Interviewee 5 worked to formally organize with community members, the PDC and outside sources, Interviewee 3 saw changes occurring within her social networks along Mississsippi.

"When I bought this place, 'T' bought a property kitty-corner next block. We stared fixing up our properties. We were key buildings, prime spots...people saw me cleaning up, others started to clean up. As ' $T$ ' and I started fixing up our buildings, people started to see that maybe there was some hope. I had people who came over and we started talking. People said 'we don't like the criminals in our neighborhood. Let's do a street watch.' They started watching out for each other. We started running the criminals off of our block."

As the community organized, they put their ideas into a document: the Albina Community Vision. The city eventually adopted this document as the Albina Community Plan in 1993 and the area was designated as a target area for city investment as an official (perhaps inaptly named) Urban Renewal Area. Interviewee 3 was a signing member.

"The Albina Plan was actually created by the leadership in the black community...these were people who knew that something had to be done in order to have the community become viable again."

The group of citizens that Interviewee 5 and others had organized began to facilitate meetings between the city planning agencies and neighborhood residents. He described the shift in the view of gentrification that happened as the community shifted from the planning phases to the implementation of revitalization.

...' in the development of that plan, the conversation often talked about gentrification. And when we-there were two thoughts on gentrification. One is 
'gentrification is good. We expect that there will be some gentrification and that's really what we're trying to achieve here.' You know, we're trying to gentrify what's going on here to some degree. The other thought was that, well, having identified and thought about it that we could manage it. We underestimated the impact that it would have, you know, on the community. And I don't think we really had a good sense of that until at least 5 or 6 years after the plan was adopted and all kinds of activity began to take place."

\section{Gentrification and the Community}

As I asked interviewees how they thought that gentrification had affected the black business community, they again referred to the weakness of the community and the damage that had been done by urban renewal. It became apparent that a vibrant black

business community had existed in lower Albina in the earlier part of the $20^{\text {th }}$ century, but had been damaged by urban renewal and then further weakened by the disinvestment and isolation of the community in the following decades. Interviewees placed very little emphasis on the black business community currently except to mention its weakness, and never spoke of that topic without specific prompting.

"..The problem is, like I said, it was so fragile that the real damage had been done 20 years ago. Do you see what I mean? To me it was in the 1980s. By 1990 it was destroyed. That's what made gentrification able to happen so fast.

The role models...the middle class--the business leadership of the black community I think was already decimated, it was already gone from inner

Albina" (Gibson Interview, 2009).

By the time that gentrification became a real concern within the community, residents and the businesses were not able to fully cope with and benefit from the changes that were occurring. Interviewee 5 expressed a disconnect between the positive changes that had been occurring in the area as a result of gentrification and the impact that those changes had had on the original residents of the community: 
"We sat down and reviewed what had gone on and we came to a couple of thoughts. One of them was if you did a windshield survey of the community based on what we saw and were trying to change, um, we'd have to give ourselves an "A." Great job, great job. But if you stepped back from it just a little bit and think about it in terms of "well, you know, there was a population that was here. It was really the people who were here that this plan was developed for, um. The plan had more physical, geographic kinds of um, goals and activities and so forth, but the benefit of all of that was supposed to extend to the citizens of that community. And so when we looked at it in that light we had to say 'well, maybe, maybe a "C." Maybe a "C.". You know? It just, um, again we really didn't appreciate, because, you know, we'd never really seen [gentrification] in Portland to that degree. We'd never really run up against the gentrification issue in that way. And it's hard to, um, it's hard to speak out against people who are there to help you."

Interviewee 5, who worked for a number of years in development for the city of Portland, discussed the process of PDC funding and how local residents found themselves unable to compete with people moving in from outside of the community for PDC funding.

"As the first home ownership programs were being developed there was a waiting list the first year or two of local people, particularly African American families and so forth, that took a lot of advantage of those programs. As more and more people came in and started doing housing and other things, they quickly outstripped the preparedness of those local families to take advantage of those programs."

Another problem with local resident participation in PDC development programs was the historical distrust that members of the black community seem to have for the organization. Karen Gibson explained that after urban renewal, the PDC could not go directly back into Albina because of public opinion there, so they partnered with the Bureau of Housing and Community Development when they initially began working with the community in the 1990s (Gibson interview, 2009). She also expressed the popular opinion that black ..."couldn't get a dime out of PDC" and the suspicion that the PDC 
seemed to be targeting whites from outside the community for their programs, as "the only one's who wanted to 'fix up the place."”

When I asked Gloria, an African American business owner who has had her business on Martin Luther King Blvd for 14 years, if she had any ties to PDC or other development programs she expressed discomfort with the PDC and mentioned the negative things that she had heard about them from other members in the community:

"Well, I've heard so much controversial things about them and a lot of it has not been good. So I just kind of stay on the edge. I don't know how familiar or involved I want to get with them. I guess their doing some real positive things for some people, but [the PDC has] a very bad reputation in the African American community, that I've heard."

This raises the issue of social embeddedness in individual economic actions (Granovetter, 1985). If members of the African American community felt that they could not trust the PDC because of its prior involvement with urban renewal, racism and with more recent suspicions regarding the influx of white community members, then black community members may not have been as willing to seek the PDC out for financial assistance. This adds another facet to the consideration of why black residents did not benefit as strongly from PDC community programs and funding.

\section{Where Are the Black Businesses?}

When asked about how the black business community is faring currently, Interviewee 5 replied "well, not very well." He again referred to the historical degradation of the community and especially the inability of the business community to recover from the effects of urban renewal. 
"Entrepreneurship is like any other, any other value. You kind of have to learn it and understand it and appreciate how it operates and so forth. You can't just one day say 'I'm an entrepreneur' it doesn't work. So, I think that that was the biggest loss that we had with this change was that there was this broken line of, you know, people owning small businesses, you know, real entrepreneurs...then all of a sudden that value stopped and was broken [by urban renewal] and then you have a group on the other side who want to try to pick it up and go along with it but they didn't have the benefit of learning from all of those, those other businesses and family members and seeing other businesses out there and so forth, so they didn't have a um, those, those ready images that they could look at. Those models. Um, those people that they could call on for mentorship, you know, to help them with their businesses and so forth. And then they didn't appreciate that they didn't have those things."

When I asked how other interviewees thought that the black business community was faring now, general consensus agreed with Interviewee 5's statement of "not very well." Sam Brooks emphasized the overarching problems to promoting black entrepreneurship within the community, first because the African American community is so small.

"African Americans are clearly at the bottom of the bottom in the state of Oregon. And there are a lot of reasons for that. Um, the numbers are small, that that's the first thing. And then if you take away the folks that are, I say, over 60, because generally they're not starting up companies. Take that group out. Take the number of people who are too young - they're probably in college or doing something. So take everybody from 22 , back. If you take all those that work for government of some sort-Portland Public Schools, city county, state, federalyou take those out of the mix, [and take] the number of people, way beyond their percentage, that are in jail. The number to actually be entrepreneurs are very small. Hardly anybody left."

And the number of black businesses appears to be declining. In the process of conducting these interviews, I came across businesses that had recently closed their doors. Gloria made the point, though, that it is hard to know now whether businesses are being affected by current unfavorable economic conditions or by gentrification. However, she still said that gentrification was a more important factor to African American owned businesses, over the economy. 


\section{Black Business in the Future}

As I asked interviewees how they thought that the black business community might fare in the future and if the potential to benefit from the changes that have occurred in the area exists, most people seemed to think that it is dependent on several factors. Gloria said that she hoped to have her business benefit from the redevelopment that is currently taking place along Martin Luther King Blvd, but she has faced challenges maintaining her customer base with the shifting of neighborhood residents.

"The immediate impact, of course, was dollars. People move out, other people don't know you're here. They go to Starbucks because it's brand-known... So in that case it's up to me to, or as a business owner, to reach out by advertising or some means to let people know that I'm here. Because it becomes a catch-22 type thing, because if the dollars aren't coming in you don't have the dollars to advertise."

She did express the supportiveness of most of the residents and felt confident that her business will be able to maintain a niche in the market.

Two of the interviewees put emphasis on ownership in the ability for residents to take advantage of the changes that are occurring in the area. Sam Brooks summed it up by saying

“...ownership is what actually changes a community... and if you don't have ownership in a community your community, by the very nature cannot grow. So when there has been little ownership in the African American community [businesses] have died off."

Interviewee 5 echoed this sentiment. When I asked if he thought that there was potential

for long-term residents to create a stronger business community in the future he said:

"It all depends, uh, it depends on a lot of things. First of all, are they renting or owning? You know, if they're owning, chances of [gentrification having] helped them are pretty good. Uh, assuming that they've got a decent income where they can continue to pay the rising tax bill. If they're renters, which 
probably suggests that their income is relatively low, particularly for singlefamily homes, um, that rent's gonna go up because the owner of that property has an investment they want to realize and they're either going to realize it through additional income through rent or their going to sell the property to somebody who wants to do something else with it."

There are also current influences that will impact the future of the black business community in Albina. Surprisingly, one of the most important may be that blacks moving to Portland from outside the area tend to be moving directly to the suburbs rather than into Albina. This was echoed in several of the interviews.

"Many of the role models, I would hypothesize, have moved out. Either to suburban locations or out of state completely. Many of the new people with money and education, like the black middle class, move directly into suburban locations and do not move into the city" (Gibson, interview, 2009).

At the same time that new African American residents have been moving to the suburbs, Albina has seen a significant population influx of African immigrants. Nikole HannahJones is a reporter who has examined the African immigrant business community in Albina. She found that as black residents of Portland have been moving out, the migration of African immigrants is what is keeping the black population of the city stable (Hannah-Jones, 2009). She also found that, for the large part, African immigrants seem to finance their businesses differently than African Americans and are not competing for the same markets. She observed:

"I don't feel like the African and African American business communities are vying for spots or they're vying for the same territory. I think the one thing is the African immigrant community has a different way of financing the businesses, so I think in some ways they are less dependent on traditional means to open a business and that allows them a little more freedom than African American community, which usually has to go through the traditional banking system."

I then probed to ask her how immigrants tend to finance their businesses. She replied: 
"they tend to pool the money. So I talked to several people. The businesses, one, tend to be pretty small, um, and when they're ready to open a business they go to other members in the community and members contribute to the business, and so several of them didn't take out bank loans at all...it's a benefit to that community because, as we know, it's harder for African Americans to get loans, they um, tend to have less collateral, less income, um, and so to have that, I think, is allowing [the Africans] to open the businesses.

\section{Conclusions}

In this inquiry I have examined the impact that gentrification has had on the black business community and entrepreneurship in the Albina district. An analysis of secondary data from the census outlined the broad changes in neighborhood demographics, economic status, and investment, while interviews with community members, business owners, and development representatives provided insight into changes within the local business community.

Several surprising key findings were made. The first is the historical significance of urban renewal and its role in eradicating black businesses that had historically thrived in lower Albina. This, coupled with the following decades of redlining, poor access to education, and increasing drug and gang activity, greatly weakened the black business community, so that by the time that gentrification became a factor in the community, it appears that residents were unable to take participate fully in the changes occurring within the area.

The second unexpected finding was that the original impetus for gentrification came from within the community, and especially from the black business leadership. As Interviewee 5 stated: 
"we tend to think of gentrification as being caused by somebody else and, not [being] able to manage it because somebody else is kind of forcing it on you... when there's a lot of responsibility, I think, on the community side of that as well."

Another factor that arose challenges the social influence theories put forward by Cutler and Glaeser (1997). They posit that segregated populations will benefit from proximity and interaction with individuals of higher socioeconomic status. But a question still remains as to whether or not new and older residents are sharing space peacefully, let alone forming positive relationships. Sam Brooks discussed the tensions that have risen between new residents old within the Alberta Neighborhood. He said that:

"the new people that came in almost were as bad as the people in earlier times who built, say, along Mississippi. Because they were as unaccommodating for African Americans and people in the community as people had been when they were openly discriminatory"

He described a community meeting where a black resident complained of the changes in the neighborhood, and how the African American legacy of the community is becoming less visible. He recounted a white resident's response:

"one of the white folks at the meeting said 'it used to be your community, it's our community now.' And that wasn't very nice and it almost started a little riot."

This is consistent with Freeman's (2006) findings on gentrification in New York. In his study he concluded that relations between new and old residents in that area were often superficial at best. If the same is true in Albina, and it is evident that tensions do remain, then it may be difficult to say that the middle class residents of Albina are having meaningful social impacts on long-term residents, which may contribute to increased entrepreneurial activity within the African American community. 
Overall, it seems that the community, which had been historically degraded, was not in a position to benefit from and take advantage of the positive changes that began occurring because of gentrification. This is consistent with Fairchild's (2008) findings, since educational attainment rates within the black community were (and continue to be) low, access and interactions with individuals from a different racial background and socioeconomic status have not been particularly beneficial entrepreneurs and business development. This coupled with the low home ownership rates within the black community and the fact that black residents tend to be leaving the area, reduces the likelihood that black community members will be able to engage in entrepreneurial activity in the future.

Certainly it seems that gentrification has provided some benefits to remaining long-term residents and business owners, especially in terms of safety, resource access, renewed economic vigor, and an improved education system. Sullivan (2007) conducted a survey in the Alberta and Eliot neighborhoods of Albina to see how residents felt about changes in their communities. He found that nearly $62 \%$ of the randomly sampled participants believed that their neighborhood had improved over the past five years. But the question still remains as to how many of the original, long-term residents have been able to stay within the community to benefit from those improvements?

A point that Interviewee 5 made was that as gentrification started to take hold in the community and changes started to occur rapidly, the residents who had initially organized 
and planned for community change felt as if they lost control of the situation and were unable to slow the progress to make sure that it benefited community residents. It seems that the community could have benefited from a proactive policy implementation aimed at creating homeownership opportunities for long-term residents and educating community members on business and residential development. However, given the community's historical distrust of the PDC and prior discrimination, it remains unclear whether programs of that nature would have had an impact of how residents coped with gentrification.

One factor that may help benefit the black community more immediately are business development programs like those being run by the Oregon Association of Minority Entrepreneurs and the Micro Enterprise Services of Oregon may help to bridge the gap between the skill sets of long term residents and the more prepared middle class residents moving into the neighborhood.

\section{Appendix: Interview Questions}

\section{Core Questions:}

-What is your history in the Community?

-How long have you/your business been in the area?

-What (if any changes have you seen in the area since you've been here/due to gentrification?

-Do you think those changes have influenced the black business community? If so, how? 
-Overall, do you think it has become easier or harder for black entrepreneurs/business owners to do business in the area?

- Do I have your permission to use your name and quotes in my report?

Business Owner Questions:

-How important is the quality of the neighborhood to your business?

-Do you have any ties to local developmental organizations (eg: PDC, Albina

Community Bank, OAME, Black United Fund)?

-Has it become easier or harder to access capital?

-Have things like property prices and physical redevelopment affected your business?

Development Representative Questions:

-What are the kinds of services that you provide?

-What is the geographic region in which you work?

-Are their particular types of businesses that you see doing well in Northeast or North Portland?

\section{Bibliography}

Byrne, J. (2003) Two Cheers for Gentrification. Howard Law Journal. 46, 1-20.

Charles, C. Z. (2003) The Dynamics of Racial Residential Segregation. Annual Review of Sociology, 29167-207.

Cutler, D. M., \& Glaeser, E. L. (1997, August). Are Ghettos Good or Bad? The Quarterly Journal of Economics, 112(3), 827-872.

Duany, A. (2001, April/May). Three Cheers for Gentrification. The American Enterprise. 36-39.

Fairchild, G. B., (2008) The Influence of Residential Segregation and its Correlates on Ethic Enterprise In Urban Areas. Journal of Business Venturing, 23, 513-527.

Fairlie, W. Robert, Meyer, Bruce D., (1996) Ethnic and Racial Self-Employment Differences and Possible Explanations. The Journal of Human Resources 31 (4) 756794.

Freeman, L., Braconi, F., (2004, Winter) Gentrification and Displacement: New York City in the 1990's. Journal of the American Planning Association 70 (1) 39-52.

Freeman, L. (2005, March) Displacement or Succession? Residential Mobility in Gentrifying Neighborhoods. Urban Affairs Review, 40 (4) 463-491. 
Freeman, L. (2006). There Goes the 'Hood. Philadelphia: Temple University Press.

Gibson, K. J., (2007) Bleeding Albina: A History of Disinvestment, 1940-2000. Transforming Anthropology, 15(1) 3-25.

Granovetter, Mark (1985) Action and Social Structure: The Problem of Embeddedness. The American Journal of Sociology, 91(3), 481-510.

Hannah-Jones, N. (2009, January 18). African immigrants help shape Portland's small black community. The Oregonian. Retrieved from http://www.oregonlive.com/news/index.ssf/2009/01/african_immigrants_help_shape.html

Massey, Douglas S., and Denton, Nancy A. 1993. American Apartheid: Segregation and the Making of the Underclass. Cambridge, Mass.: Harvard Univ. Press.

Massey, Douglas S. and Denton, Nancy A. (7/1/2003) The Geography of Inequality in the United States, 1950-2000 Brookings-Wharton Papers on Urban Affairs 15287084(4), 1-40.

Newman, Kathe and Wyly, Elvin K. (2003, January) The Right to Stay Put Revisited: Gentrification and Resistance to Displacement in New York City. Urban Studies, 43(1) 23-57.

Ovadia, S. (2003, December). The Dimensions of Racial Inequality: Occupational and Residential Segregation Across Metropolitan Areas In the United States. City and Community, 2(4), 313-333.

Porter, Michael, E. (1995, May-June). The Competitive Advantage of the Inner City. Harvard Business Review. 73(3), 55-71.

Reardon, S. F., Matthews, S. A., O’Sullivan, D., Lee, B. A., Firebaugh, G., Farrell, C. R., Bischoff, K. (2008, August) The Geographic Scale of Metropolitan Racial Segregation. Demography, 45(3) 489-514.

Sethi, R., Somanathan, R., (2004). Inequality and Segregation. Journal of Political Economy, 112(6), 1296-1321.

Smith, D. (2005, November) Developing Self-Employment Among African Americans: The Impact of Household Social Resources on African American Entrepreneurship. Economic Development Quarterly. 19(4), 346-355.

Sullivan, Daniel M. (2007, March) Reassessing Gentrification: Measuring Resident's Opinions Using Survey Data. Urban Affairs Review, 42(4) 583-592.

Timberlake, J. M. (2002, September) Separate but How Unequal? Ethnic Residential Stratification, 1980 to 1990. City and Community 1 (3) 251-266. 
Vigdor, J., Matlack, J. (2006, June) Do Rising Tides Lift All Prices? Income Inequality and Housing Affordability. Working Paper 12331. National Bureau of Economic Research. 